\title{
Lugares e trânsitos de imagens na licenciatura em artes visuais a distância
}

\section{ALEXANDRE GUIMARÃES}

Resumo

A Faculdade de Artes Visuais da UFG oferece, desde 2007, dois cursos de licenciatura em artes visuais na modalidade a distância, fomentando a necessidade de projetos de pesquisa que retro-alimentem, reflexivamente, graduação e pós-graduação. Este projeto propõe investigar o uso de imagens nas mediações pedagógicas de ensino e aprendizagem neste contexto. Qual o lugar dessas imagens, seus trânsitos e sentidos? Existem diferenças com a produção da imagem no ensino a distância em contraponto com o ensino tradicional? Acredito que esta nova ambiência de aprendizagem formatada em interfaces e hipertextos leva a experiências híbridas e multiculturais que dialogam com uma educação para a cultura visual. 